\title{
GENEZA HEREZJI WCZESNOCHRZEŚCIJAŃSKICH W UJECCIU FILASTRIUSZA Z BRESCII
}

W kwestii genezy zjawiska herezji, rozumianego jako błąd doktrynalny, pozostający w sprzeczności z zasadniczymi prawdami wiary, zawartymi w regula fidei, teologowie epoki patrystycznej zajmowali złożone stanowisko. $\mathrm{Z}$ jednej strony wywodzono herezje chrześcijańskie z błędów, które zrodziły się w łonie judaizmu, np. od sekt powstałych w Samarii ${ }^{1}$. Z drugiej - uważano, że prototyp herezji stanowiły rozbieżne stanowiska w starożytnych szkołach filozoficznych, odbiegające od pierwotnej nauki założyciela danego nur$\mathrm{tu}^{2}$. Dopatrywano się także wpływu dyskusyjnych poglądów filozoficznych, zwłaszcza epikurejskich, takich jak negowanie opatrzności Bożej czy dążenie do przyjemności jako główny cel życia, na formowanie się błędnych ujęć doktryny chrześcijańskiej ${ }^{3}$.

${ }^{*}$ Ks. prof. dr hab. Mariusz Szram - profesor zwyczajny w Katedrze Patrologii Greckiej i Łacińskiej w Instytucie Historii Kościoła i Patrologii na Wydziale Teologii Katolickiego Uniwersytetu Lubelskiego Jana Pawła II; e-mail: m.szram@wp.pl.

${ }^{1}$ Z Samarii pochodził Szymon Mag (por. Dz 8, 9-24), uważany zgodnie przez autorów wczesnochrześcijańskich katalogów herezji, a więc także przez Filastriusza, za pierwszego herezjarchę chrześcijańskiego, protoplastę gnostyków. Por. Iustinus, Apologia I 26, 2-3; tamże 56; Epiphanius, Panarion II 21; Theodoretus, Haereticarum fabularum compendium 1; Filastrius Brixiensis, Diuersarum hereseon liber 29; Augustinus, De haeresibus 1; Isidorus Hispalensis, De haeresibus liber 3; Joannes Damascenus, De haeresibus 21. Zob. A. Le Boulluec, La notion d'hérésie dans la littérature grecque: II et III siècles, t. 1: De Justin à Irénée, Paris 1985, 80-84.

${ }^{2}$ Por. Iustinus, Dialogus cum Iudaeo Tryphone 2, 1-2. A. Le Boulluec dowodzi na podstawie innych tekstów Justyna (por. Dialogus cum Iudaeo Tryphone 62, 3; tamże 80, 4), że w filozofii greckiej upatrywał on genezy herezji jedynie w znaczeniu odłamu wprowadzającego różnorodność w nauczanie uznane za jedyną mądrość, natomiast zawartość treściową wczesnochrześcijańskich doktryn heretyckich porównywał przede wszystkim z sektami żydowskimi, które na gruncie religijnym, a nie filozoficznym, wprowadzały błędne rozumienie słowa Bożego. Zob. Le Boulluec, La notion d'hérésie, t. 1, s. 52-64; tamże, s. 71: „Dans le cas de la philosophie, une façon de parler courante servait à dénoncer seulement la diversité des écoles en l'opposant à l'unité de la sagesse. Dans le cas du judaïsme, plus proche du christianisme, comme religion, et surtout comme prédécesseur, c'est la parole même de Dieu qui selon Justin dénonce le mensonge".

${ }^{3}$ Por. Clemens Alexandrinus, Stromata VI 67, 1-2. W przekonaniu Klemensa, patrzącego na filozofię starożytną z chrześcijańskiego punktu widzenia, epikureizm był nurtem o charakterze odszczepieńczym, czyli w pewnym sensie „heretyckim”, w stosunku do innych nurtów filozoficznych, 
Biskup Brescii z 2. poł. IV w. Filastriusz ${ }^{4}$, autor najstarszego zachowanego łacińskiego katalogu herezji, napisanego kilka lat po powstaniu słynnego $\mathrm{Pa}$ narionu Epifaniusza z Salaminy ${ }^{5}$, również przedstawił w kwestii genezy herezji wczesnochrześcijańskich własne stanowisko, w którym zastosował trojakiego rodzaju argumentację: teologiczną, moralną i historyczno-kulturowa. W tym ostatnim podejściu połączył w swoisty sposób wspomniane poglądy rozpowszechnione w starożytnym Kościele, wywodzące wczesnochrześcijańskie ruchy heretyckie z sekt judaistycznych lub z greckiej filozofii.

\section{Argumentacja teologiczna - herezje pochodzą od szatana jako „ojca} klamstwa". Filastriusz określał herezje nie tylko technicznym terminem here$s i{ }^{6}$, ale także pojemnym znaczeniowo rzeczownikiem error - „błąd”, „mylne wyobrażenie"7 lub czasownikiem errare - „błądzić”, „mylić się”, wskazując

zawierających ziarna Bożej mądrości, jak platonizm i stoicyzm. Zob. Boulluec, La notion d'hérésie, t. 1, s. 271-272 i 274.

${ }^{4}$ Traktat Diuersarum hereseon liber Filastriusza z Brescii zawiera syntetyczny opis 156 herezji: 28 w łonie judaizmu i 128 we wczesnym chrześcijaństwie. Wzorował się na nim św. Augustyn pisząc swoje dziełko De haeresibus. Por. G. Bardy, Le „De haeresibus” et ses sources, w: Miscellanea agostiniana, t. 2, Roma 1931, 397-416. W niniejszym artykule korzystam z najnowszego wydania tekstu: Filastrius Brixiensis, Diuersarum hereseon liber, ed. F. Heylen - G. Banterle, Scriptores circa Ambrosium 2, Milano - Roma 1991 (wcześniejsze wydania: ed. F. Marx, CSEL 38, Vindobonae 1898; ed. F. Heylen, CCL 9, Turnholti 1957). Wszystkie cytaty z tego dzieła przytaczam w przekładzie własnym.

${ }^{5}$ Epifaniusz napisał swoje najsłynniejsze dzieło najprawdopodobniej w latach 373-378. Por. M. Gilski, Epifaniusz z Salaminy i jego „Panarion”, w: Epifaniusz z Salaminy, Panarion. Herezje 1-33. Tekst grecki i polski, przekład i wstęp M. Gilski, opr. i kom. A. Baron, Kraków 2015. Traktat Filastriusza jest datowany na lata 380-388. Por. G. Banterle, Introduzione, w: Filastrius Brixiensis, Diuersarum hereseon liber, s. 11; J. McClure, Handbooks against Heresy in the West, from the Late Fourth to the Late Sixth Centuries, JTS 30 (1979) 186-197.

${ }^{6}$ Opis każdej herezji rozpoczyna Filastriusz od frazy ,alia est heresis” (por. Filastrius Brixiensis, Diuersarum hereseon liber 136, 1, ed. Heylen - Banterle, s. 184) lub „sunt quidam heretici” (por. tamże 147, 1, ed. Heylen - Banterle, s. 200).

${ }^{7}$ Por. tamże Praefatio 1, ed. Heylen - Banterle, s. 24: „De hereseon diuersa pestilentia uariisque erroribus qui ab origine mundi emerserint et sub Iudaeis defluxerint et ex quo uenit dominus noster Iesus salvator in carne pullulauerint”; tamże 33, 1, ed. Heylen - Banterle, s. 52: ,a sana doctrina diuersis erroribus [...] pessumdatus est”; tamże 36, 1, ed. Heylen - Banterle, s. 56: „Cerinthus successit huius errori”; tamże 45, 1, ed. Heylen - Banterle, s. 62: „[Marcion] interrogans presbiteros sanctos ecclesiae catholicae sensus sui eis erroris mortiferi proponebat"; tamże 54, ed. Heylen - Banterle, s. 70: ,Sabellius [...] similitudinem sui doctoris [Noeti] itidem secutus est et errorem"; tamże 119, 1, ed. Heylen - Banterle, s. 152: „Sunt quidam qui turbantur heretici de Deuteronomio, [...] non paruo ducuntur errore aliter sentientes”; tamże 130, 1, ed. Heylen - Banterle, s. 172: „Sunt alii heretici qui de inaequalitate psalterii errorem patiuntur non modicum, aestimantes omnem librum psalterii non esse Dauid beatissimi”; tamże 144, ed. Heylen - Banterle, s. 198: „non paruum errorem incurrunt, diuersa itidem sentientes de fide catholica".

${ }^{8}$ Por. tamże 37, 1, ed. Heylen - Banterle, s. 56: „Hebion discipulus eius Cerinthi, in multis ei similiter errans saluatorem nostrum hominem de Ioseph natum carnaliter aestimabat"; tamże 71, 1, ed. Heylen - Banterle, s. 84: „Alii autem sunt heretici qui circa passionem aberrant quod in passione 
na obecne w ruchach heterodoksyjnych zjawisko wypaczenia nie tylko chrześcijańskiej doktryny, ale także moralności i obrosłych tradycją liturgicznych i prawnych praktyk Kościoła, oraz krytykując przejawy niewłaściwej egzegezy biblijnej, zwłaszcza literalnej. Usiłując wskazać istotę herezji biskup Brescii używał przede wszystkim terminów wyrażających odejście od prawdy, takich jak: falsitas - „fałsz”, falsus - „fałszywy”10; fallacia - „kłamstwo”, „oszustwo" "11; fallax - „Zwodniczy”, „,kłamliwy”"; mendacium - „kłamstwo"13; uanitas - „marność”, „kłamstwo”, „fałsz”, „błąd”, „przewrotność”14; uanus - „Zwodniczy”, „kłamliwy”, „fałszywy”"15; inanis - „pozorny”, „zmyślony”16. Przykładowo doktrynę Marcjona i jego mistrza Cerdona nazwał kłamstwem (mendacium), ponieważ - podobnie jak wiele nurtów gnostycyzujących - głosili, że jest dwóch bogów: dobry i zły ${ }^{17}$. Podobnie mianem próżnego i zwodniczego (uanitas) określił Filastriusz pogląd o wpółwieczności materii z Bogiem, głoszony przez heretyków z Galacji - Seleucjusza i Hermiasza ${ }^{18}$. W innym miejscu do błędów i fałszerstw (errores atque falsitas) zaliczył doktrynę montanistów, donatystów oraz kontynuujących ich zwyczaje zwolenników

dimiserit dominus noster Christus carnem”; tamże 125, 3, ed. Heylen - Banterle, s. 160-162: „poetas falsos et uanos filosofos qui aestimat posse saluari rebelles dei, errat illis peius et a ueritate dissentit".

${ }^{9}$ Por. tamże 83, ed. Heylen - Banterle, s. 96: ,[Parmenianus] qui eorum nuper [scil. Donatianorum] successit erroribus atque falsitati”.

${ }^{10}$ Por. tamże 49, 3, ed. Heylen - Banterle, s. 66: „separant se a catholica ecclesia propter illos suos pseudoprophetas et falsos doctores".

${ }^{11}$ Por. tamże 33, 1. 7, ed. Heylen - Banterle, s. 52. 54: „[Nicolaus Antiochenus] a sana doctrina diuersis $[\ldots]$ fallaciis pessumdatus est [...]. Alii autem euangelium consummationis et uisiones inanes et plenas fallaciae et somnia uidere diuersa adserunt delirantes".

${ }^{12}$ Por. tamże 38, 1, ed. Heylen - Banterle, s. 58: „[Valentinus] numerositatis notitiam fallacissimam praedicans, multorumque animas ignorantium captiuauit".

${ }^{13}$ Por. tamże 61, 4, ed. Heylen - Banterle, s. 76: „[Manichei] ut latrones iam sub figura confessionis Christianae multorum animas mendacio ac pecudali turpitudine non desinunt captivare"; tamże 84, 6, ed. Heylen - Banterle, s. 98: „[abstinentes] sentiunt [...] creaturam non a deo esse creatam, sed a diabolo eam factam [...] perque hoc mendacio multorum animas captiuarunt".

${ }^{14}$ Por. tamże 55, 1, ed. Heylen - Banterle, s. 70: „Quae est haec uanitas Galatarum, Seleuci et Hermiae hereticorum?”; tamże 76, 3, ed. Heylen - Banterle, s. 88: „[Passalorinchitae] Pythagoricam uanitatem potius quam prophetarum caelestem uitam et sapientiam sequi properantes”.

${ }^{15}$ Por. tamże 38, 1, ed. Heylen - Banterle, s. 58: „[Valentinus] uanam quandam ac perniciosam doctrinam eructans”; tamże 39, ed. Heylen - Banterle, s. 58: „Ptolemeus, qui doctrinam aeque uanam intulit”; tamże 81, ed. Heylen - Banterle, s. 94: „quae magis humana ac uanae superstitionis sunt, non traditionis sanctorum ac domini nostri Iesu Christi"; tamże 82, 2, ed. Heylen - Banterle, s. 94: „[Nouatiani] uanam doctrinam conati sunt seminare".

${ }^{16}$ Por. tamże 79, 1, ed. Heylen - Banterle, s. 88: „[Coluthiani] ferebantur inani, nescierunt potentiam rationis”; tamże 86, 1, ed. Heylen - Banterle, s. 98: „Alii autem sunt qui cum hominibus non sumunt escas, praesumptione ducti inani".

${ }^{17}$ Por. tamże 45, 3, ed. Heylen - Banterle, s. 62: „[Marcion] Cerdonis sui doctoris firmabat mendacium et iste similiter unum deum bonum et unum malum adnuntians".

${ }^{18}$ Por. tamże 55, 1, ed. Heylen - Banterle, s. 70: „haec uanitas Galatarum, Seleuci et Hermiae hereticorum $[\ldots]$ qui $[. .$.$] materiam mundi coaeternam esse cum deo adserunt".$ 
niejakiego Parmeniana, którzy chrzcili ponownie ludzi w przekonaniu, że ich chrzest przewyższa ten udzielany w Kościele katolickim ${ }^{19}$.

Wszystkie powyższe określenia biskupa Brescii były mniej lub bardziej bezpośrednimi odwołaniami do postaci szatana jako „niezwykle kłamliwego ojca" (parens mendacissimus) ${ }^{20}$, który jest pierwszym i najważniejszym sprawcą fałszowania prawd wiary ${ }^{21}$. Charakteryzując herezję manicheizmu Filastriusz nie tylko posłużył się inwektywą, nazywając zwolenników tego ruchu:

„bandytami (latrones) udającymi wiarę chrześcijańską [dosł. pod postacią wyznania chrześcijańskiego (sub figura confessionis Christianae)], którzy nie przestają porywać dusz wielu [osób] za pomocą kłamstwa (mendacio) i bestialskiej obrzydliwości (pecudali turpitudine)"'22,

ale także nawiązał do „satanistycznych” elementów ich doktryny, skądinąd sprzecznych ze sobą: z jednej strony manichejczycy czczą demony (daemones colentes), z drugiej - uznają, że godne pogardy ludzkie ciało zostało stworzone przez szatana (corpus autem a diabolo factum arbitrantur $)^{23}$.

Jako zdeklarowany zwolennik alegorycznej interpretacji Biblii - czemu dał wyraz na wielu kartach swojego katalogu herezji ${ }^{24}$ - Filastriusz w krótkim wstępie do tego dzieła wyprowadził duchowy sens z passusu zaczerpniętego z Księgi Jeremiasza: „Zawołała kuropatwa, zebrała tych, których nie zrodziła, zbierając sobie bogactwa w niemądry sposób; w środku dni opuszczą ją one i ostatecznie okaże się nierozumna" (Jr 17, 11, Septuaginta). Odwołując się do negatywnej antycznej symboliki kuropatwy autor dostrzegł w tym obrazie

${ }^{19}$ Por. tamże 83, ed. Heylen - Banterle, s. 96: „Montenses, qui [...] supra baptismum ecclesiae catholicae alium suum baptisma insaniunt promittenses; qui et Donatiani dicuntur [...]; qui et Parmeniani nunc appellantur a Parmeniano quodam, qui eorum nuper successit erroribus atque falsitati”.

${ }^{20}$ Por. tamże Praefatio 3, ed. Heylen - Banterle, s. 24: ,amissa falsitate parentis mendacissimi [scil. diabolo], iam ueri parentis Christi uestigia sequi omnis homo non moratur agnoscens".

${ }^{21} \mathrm{Na}$ demoniczną genezę herezji wczesnochrześcijańskich zwrócił uwagę już Justyn (Dialogus cum Iudaeo Tryphone 7, 1; tamże 35, 2), stwierdzając, iż w przeciwieństwie do proroków, którzy przemawiali z natchnienia Ducha Świętego, twórcy sekt są opętani przez diabła, a także oskarżając heretyków, że ich nauczanie pochodzi od duchów wprowadzających w błąd. Podobnie Ireneusz z Lyonu (Adversus haereses V 25) uważał herezję za szatańską apostazję i wiązał ją z osobą Antychrysta. Por. Le Boulluec, La notion d'hérésie, t. 1, s. 64-67 i 181-184.

${ }^{22}$ Filastrius Brixiensis, Diuersarum hereseon liber 61, 4, ed. Heylen - Banterle, s. 76.

${ }^{23}$ Por. tamże 61, 3, ed. Heylen - Banterle, s. 76. W podobnych słowach charakteryzował gnostycko-manichejską sektę wstrzemięźliwych (abstinentes), działającą w Galii, Hiszpanii i Akwitanii. Por. tamże 84, 6, ed. Heylen - Banterle, s. 98: „escas [...] non esse bonas, et ita non a deo hominibus escae causa fuisse concessas, sed a diabolo factas ut adserant, ita sentiunt inque hoc iam creaturam non a deo creatam, sed a diabolo eam factam". Pogląd o stworzeniu ciał przez diabła głosili też patrycjanie, którzy doszli do takiej skrajności w potępianiu ludzkiej cielesności, że niektórzy z nich nie wahali się nawet wydać siebie na śmierć. Por. tamże 62, 1-2, ed. Heylen - Banterle, s. 76 : „Patriciani [...] carnem hominis non a deo factam adserunt, sed a diabolo arbitrantur. [...] quidam de eis sibi mortem inferre non dubitauerint".

${ }^{24}$ Por. tamże 149-155, ed. Heylen - Banterle, s. 204-222. 
biblijnym przedstawienie przewrotnej natury i sposobu działania diabła, który odrywa w podstępny sposób ludzi od prawdy, przekonując, że ich własny sposób myślenia jest właściwy ${ }^{25}$.

Heretycy są więc - w przekonaniu Filastriusza - ludźmi uprowadzonymi przez szatana, którzy stracili rozeznanie, gdzie należy szukać prawdziwej nauki o Bogu i człowieku. Istnieli oni już przed przyjściem Chrystusa, od początku świata. Opis herezji istniejących w środowisku żydowskim biskup Brescii rozpoczął od przedstawienia dwóch ruchów związanych z opacznym rozumieniem opisu początków ludzkości w Księdze Rodzaju: ofitów i kainitów, których cechą wspólną było przypisywanie diabłu wyjątkowej mocy, większej niż ta, którą dysponuje sam Bóg, i w konsekwencji oddawanie mu wyjątkowej czci. Ofici, zwani także serpentynami, czcili węża twierdząc, że zapoczątkował on w ludziach poznanie dobra i zła, natomiast Bóg mu zazdrościł, iż jako pierwszy udzielił kobiecie poznania rzeczy dobrych i złych, co rozszerzyło się przez nią na cały rodzaj ludzki, i za karę został strącony z nieba ${ }^{26}$. Kainici natomiast wychwalali bratobójcę Kaina, twierdząc, że Abel nie uszanował większej mocy, która była w Kainie i w ten sposób sprowokował go do morderstwa ${ }^{27}$. Omawiając inną z herezji powstałych w czasach starotestamentalnych w łonie judaizmu - oddającą cześć Pytonissie z Endor, która na życzenie króla Saula przywołała z otchłani ducha zmarłego Samuela (por. 1Sm 28, 3-25) - Filastriusz dopatrywał się w tego rodzaju praktykach, polegających na wywoływaniu zmarłych i przekazywaniu przez nich orędzia pochodzącego rzekomo z natchnienia Bożego, działania ducha nieczystego (immundus spiritus), który podszywa się pod anioła światłości i zwodzi ludzi ${ }^{28}$.

Po objawieniu się Syna Bożego, heretycy pojawili się także we wspólnocie Kościoła, rozbijając jej jedność i wprowadzając fałszywe nauki, zgodnie z natura „ojca kłamstwa”. Ostatecznie jednak - jak przewiduje biskup Brescii - oderwą się od sprawcy błędu i powrócą do prawdziwych rodziców, czyli do Boga i Kościoła ${ }^{29}$.

Z teologicznego punktu widzenia geneza herezji tkwi więc w przewrotnym i zwodniczym działaniu diabła, który odciaga ludzi od źródła prawdy, równocześnie przekonując ich podstępnie, że postępują dokładnie odwrotnie. To zachowanie szatana przybierało w historii różne formy, które stały się - zdaniem Filastriusza - przykładem do naśladowania dla heretyków chrześcijańskich.

${ }^{25}$ Por. tamże Praefatio 1-4, ed. Heylen - Banterle, s. 24-26.

${ }^{26}$ Por. tamże 1, 1, ed. Heylen - Banterle, s. 26.

${ }^{27}$ Por. tamże 2, ed. Heylen - Banterle, s. 26.

${ }^{28}$ Por. tamże 26, 1-7, ed. Heylen - Banterle, s. 44-46.

${ }^{29}$ Por. tamże Praefatio 3, ed. Heylen - Banterle, s. 24: „diabolo relicto impietatis causa eius qui orbem terrarum sui sub dicione ac potestate eum tenere putaret, postque uero Christo parente a nobis uiso et recognito, amissa falsitate parentis mendacissimi, iam ueri parentis Christi uestigia sequi omnis homo non moratur agnoscens". 
2. Argumentacja moralna - do herezji prowadzi pycha i nieumiarkowanie w poznaniu Boga. Pochodną argumentacji teologicznej w kwestii genezy zjawiska herezji była w myśli patrystycznej argumentacja moralna, związana z odpowiedzią człowieka na pokusę fałszowania prawdy pochodzącą od szatana. Jądro tej argumentacji stanowiła przesłanka dotycząca głównej wady moralnej, która legła u podstaw buntu szatana, a w konsekwencji stała się powodem rozbicia jedności doktrynalnej i instytucjonalnej Kościoła przez heretyków i schizmatyków. Wadą tą, szczególnie piętnowaną we wczesnochrześcijańskiej literaturze monastycznej, a także przez współczesnych Filastriuszowi greckich autorów IV w., Ojców Kapadockich ${ }^{30}$ i Jana Chryzostoma ${ }^{31}$, a nieco później na Zachodzie przez Augustyna ${ }^{32}$, była pycha ( $\tau \hat{v} \varphi \varsigma^{33}$, $v \pi \varepsilon \rho \eta \varphi \alpha v i \alpha^{34}$, $\alpha \lambda \lambda \alpha \zeta_{0} v^{2} \alpha^{35}$, superbia ${ }^{36}$ ) i towarzyszący jej brak posłuszeństwa. Bazyli Wielki określił pychę eunomian jako nieodpartą chęć przeniknięcia umysłem ludzkim substancji samego Boga, podczas gdy jest ona niedostępna, a ludzie nie potrafią zgłębić do końca nawet natury otaczającego ich świata ${ }^{37}$. Również Grzegorz z Nazjanzu, polemizując z arianami, w wadzie pychy dostrzegał główną przyczynę powstawania błędnych nauk teologicznych. Nieumiarkowanie w mówieniu o Bogu i pozbawione poszanowania tajemnicy zagłębianie się w Jego naturę uznał za szczególne zagrożenie dla każdego duchownego i teologa ${ }^{38}$. Augustyn, definiując heretyka, wskazywał na następujące motywy

${ }^{30}$ Por. Basilius Caesariensis, Adversus Eunomium 1, 13; Gregorius Nazianzenus, Orationes 36, 5; Gregorius Nyssenus, De virginitate IV 2, 11-15. Zob. M. Szram, Cnota pokory w nauczaniu greckich Ojców Kościoła IV wieku, Lublin 2014, 149-158. Bazyli poświęcił problemowi pychy całą jedną homilię, która zachowała się jedynie w przekładzie arabskim. Por. Basilius Caesariensis, Homilia de superbia, ed. J. Muyser: Homiliae des hl. Basilius über den Hochmut der Jugend und die Demut des Alters (arabice), Kairo 1954.

${ }^{31}$ Por. Joannes Chrisostomus, In Johannem hom. 16, 4; tenże, In Matthaeum hom. 65, 5. Zob. Szram, Cnota pokory, s. 159-169.

${ }^{32}$ Por. Augustinus, De civitate Dei 7, 33; tamże 12, 6. Zob. S. Witek, Interpretacja pokory w patrystyce zachodniej, RTK 17 (1970) z. 3, 5-24; A. Eckmann, Nauka świętego Augustyna o pokorze jako podstawie ascezy chrześcijańskiej, w: Wczesnochrześcijańska asceza. Zagadnienia wybrane, red. F. Drączkowski - J. Pałucki, Lublin 1993, 83-97.

${ }^{33}$ Basilius Caesariensis, Adversus Eunomium 1, 13, ed. B. Sesboüé - G.-M. de Durand - L. Doutreleau, SCh 299, Paris 1982, 218; Gregorius Nyssenus, De mortuis non esse dolendum, ed. G. Heil, GNO 9: Sermones, Leiden 1967, 59.

${ }^{34}$ Basilius Caesariensis, De humilitate hom. 1, PG 31, 525C; Gregorius Nazianzenus, Orationes 4, 32, ed. J. Bernardi, SCh 309, Paris 1983, 128-130; Gregorius Nyssenus, De vita Moysis II 280, 5-6, ed. J. Daniélou, SCh 1bis, Paris 1987, 296.

${ }^{35}$ Basilius Caesariensis, De humilitate hom. 3, PG 31, 532A; Joannes Chrisostomus, In Ozias hom. (In illud: Vidi Dominum) IV 3-4, ed. J. Dumortier, SCh 277, Paris 1981, 156-158. Zob. Szram, Cnota pokory, s. 76-79, 82, 86-87 i 90-91.

${ }^{36}$ Por. Filastrius Brixiensis, Diuersarum hereseon liber 128, 7, ed. Heylen - Banterle, s. 168; tamże 137, 1, ed. Heylen - Banterle, s. 184.

${ }^{37}$ Por. Basilius Caesariensis, Adversus Eunomium 1, 13. Zob. Szram, Cnota pokory, s. 151.

${ }^{38}$ Por. Gregorius Nazianzenus, Orationes 27, 3. Zob. Szram, Cnota pokory, s. 153-154. Pod-

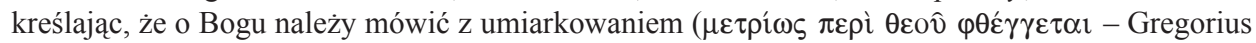


jego zachowań: szukanie własnej chwały, chęć zdobycia władzy, oczekiwanie doczesnych korzyści ${ }^{39}$.

Filastriusz w swoim dziele reprezentował podobne stanowisko, zbieżne z oceną motywów działania heretyków przez Epifaniusza z Salaminy, piętnującego w swoim katalogu herezji np. skrajną zarozumiałość i zuchwalstwo Szymona Maga i Menandra, którzy uważali się za moc Bożą zesłaną z nieba ${ }^{40}$. O Walentynie biskup Brescii pisał, że zaczął głosić błędną naukę, ponieważ popadł w pychę ${ }^{41}$. Pokusa wywyższania się i uznania się za doskonałych legła u podstaw powstania ugrupowania nowacjan. Zwolennicy Nowata z Kartaginy, rozgniewani z powodu przyjęcia do Kościoła wielu chrześcijan upadłych podczas prześladowań, ale odbywających pokutę, oddzielili się od wspólnoty Kościoła, kierując się - jak pisze Filastriusz - „uprzedzeniem i pychą” (praesumptione [...] ac superbia $)^{42}$. O szczególną zarozumiałość i zuchwalstwo oskarżył biskup Brescii heretyków wyciagających z biblijnego stwierdzenia o stworzeniu człowieka na obraz i podobieństwo Boże (por. Rdz 1,27) platonizujący wniosek o boskości ludzkiej duszy, a zapominających, że została ona stworzona aktem Boskiej łaski z niczego i jest tylko do Boga podobna, a nie boska $\mathrm{z}$ własnej natury ${ }^{43}$.

\section{Argumentacja historyczno-kulturowa - herezje chrześcijańskie wywodzą się z wcześniejszych ruchów żydowskich i starożytnych szkół filozoficznych.}

a) Geneza judaistyczna. Struktura dzieła Filastriusza - zbudowana na dwupodziale: herezje judaistyczne i chrześcijańskie - wskazuje na

\footnotetext{
Nazianzenus, Orationes 32, 19, ed. P. Gallay - C. Moreschni, SCh 318, Paris 1985, 124), Grzegorz odwoływał się do antycznej zasady umiaru ( $\mu \varepsilon \sigma o ́ \tau \eta \varsigma)$, która polegała na zachowaniu złotego środka między nadmiarem i brakiem nie tylko w czynnościach codziennego życia, jak np. jedzenie, ale także w myśleniu i mówieniu. Zob. S.S. Harakas, Ethical Teaching in Saint Gregory the Theologian's

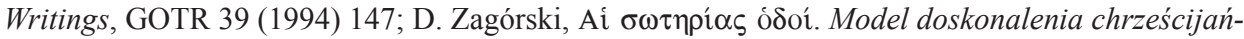
skiego w świetle ekshortacji pastoralnych Grzegorza z Nazjanzu, Toruń 2007, 95-96.

${ }^{39}$ Por. Augustinus, De utilitate credendi 1. Zob. M. Fiedrowicz, Teologia Ojców Kościoła. Podstawy wczesnochrześcijańskiej refleksji nad wiarq, Kraków 2009, 419; N. Widok, Ortodoksja, herezja, schizma - wyjaśnienie pojęć, w: Ortodoksja, herezja, schizma w Kościele starożytnym, red. F. Drączkowski - J. Pałucki - P. Szczur - M. Szram - M. Wysocki - M. Ziółkowska, Lublin 2012, 28.

${ }^{40}$ Por. Epiphanius, Panarion II 21, 2, 3; tamże II 22, 1, 2.

${ }^{41}$ Por. Filastrius Brixiensis, Diuersarum hereseon liber 38, 2, ed. Heylen - Banterle, s. 58: „Elatior autem factus postmodum errore non paruo deceptus est”. Tertulian upatruje genezy walentynianizmu w rozczarowaniu Walentyna, który słynąc z inteligencji i elokwencji spodziewał się biskupstwa. Por. Tertullianus, Contra Valentinianos 4, 1, ed. J.-C. Fredouille, SCh 280, Paris 1980, 86: „Sperauerat episcopatum Valentinus, quia et ingenio poterat et eloquio".

${ }^{42}$ Por. Filastrius Brixiensis, Diuersarum hereseon liber 82, 2-3, ed. Heylen - Banterle, s. 94: „In persecutione autem, quia lapsi sunt multi fideles et in paenitentiam suscepti sunt a catholica ecclesia, irati, immo potius praesumptione ducti ac superbia, uanam doctrinam conati sunt seminare".

${ }^{43}$ Por. tamże 137, 1, ed. Heylen - Banterle, s. 184: ,nesciunt quid sit imago de natura proprietatis, et quid positionis sit gratia, non paruam sibi praesumunt superbiam dignitatis".
} 
opowiedzenie się przez niego za koncepcją żydowskiej genezy heterodoksyjnych ruchów wczesnochrześcijańskich. Podobnie postąpił Epifaniusz, wyszczególniając jako odrębną grupę obok ruchów żydowskich herezje powstałe wśród Samarytan (esseńczycy, sebuaje, goroteni, dozyteni) ${ }^{44}$, co wskazuje na panujące wówczas przekonanie o szczególnie herezjogennym charakterze tego środowiska. Biskup Brescii odwołał się zarówno do ugrupowań uchodzących za nieortodoksyjne wśród samych Żydów Starego Testamentu, jak i do takich, które funkcjonowały w głównym nurcie judaizmu, nie mogły być jednak uznane za zgodne $\mathrm{z}$ wiarą chrześcijańską ${ }^{45}$. Ze sposobu przedstawienia poszczególnych 28 ruchów żydowskich uznanych przez Filastriusza za heretyckie wynika kilka zasadniczych cech tych ugrupowań i ich poglądów, mogących być wzorem dla błędnych odłamów w chrześcijaństwie: opaczna interpretacja biblijnych tekstów starotestamentalnych, wątpliwości co do związku osoby Mesjasza ze sferą boska, odrzucanie zmartwychwstania oraz gloryfikowanie rzeczywistości materialnej i ciała ludzkiego.

Istotną przyczyną powstawania błędnych doktryn w judaizmie, a potem w chrześcijaństwie, była przede wszystkim niewłaściwa interpretacja opowiadań biblijnych, wynikająca z niezrozumienia kontekstu wypowiedzi autora biblijnego oraz naginania tekstu do własnych z góry przyjętych koncepcji obcych duchowi Pisma, co często zdarzało się później w chrześcijaństwie, np. w ruchach gnostycyzujących ${ }^{46}$. Przykładem takiej egzegetycznej genezy herezji żydowskich moga być interpretacje wydarzeń z Ksiegi Rodzaju przez ugrupowania przypisujące upadłemu aniołowi, symbolizowanemu przez węża, większą moc niż Bogu Stwórcy oraz dobrą intencję zapoczątkowania w ludziach poznania dobra i zła ${ }^{47}$; a także poglądy czcicieli zwierząt, które

${ }^{44}$ Por. Epiphanius, Panarion I 10-13. Stanowisko Epifaniusza w tej kwestii wiernie powtarza Jan Damasceński (De haeresibus 9-13). Filastriusz traktuje samarytan ogólnie jako jedną z wielu herezji żydowskich, nie wyszczególniając oddzielnych grup. Por. Filastrius Brixiensis, Diuersarum hereseon liber 7, 1-2, ed. Heylen - Banterle, s. 30: „Zachowują Prawo Mojżesza, to znaczy tylko cztery księgi [z wyjątkiem Księgi Powtórzonego Prawa - M.S.]; nie oczekują na przyszły sąd, przeczą zmartwychwstaniu; nie wierzą, że Chrystus Pan, Syn Boży był zapowiadany w Prawie i u Proroków".

${ }^{45}$ Należy także pamiętać, że nazywanie przez samych zhellenizowanych Żydów niektórych nurtów judaizmu herezjami, nie zawsze oznaczało potępienie nauczania ich przedstawicieli, po-

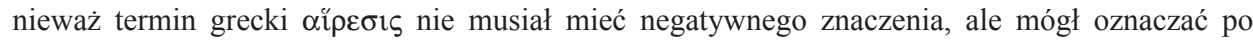
prostu ugrupowanie o określonych poglądach czy szkołę filozoficzną. Por. Le Boulluec, La notion d'hérésie, t. 1, s. 71: „À l'époque où existaient certains de ces courants du judaïsme, comme les Sadducéens et les Pharisiens, le mot grec pour les designer était bien hairesis. Mais cette appellation n'était pas péjorative, et n'excluait pas du judaïsme authentique".

${ }^{46}$ Ireneusz z Lyonu (Adversus haereses I 1,6) i Orygenes (Commentarii in Evangelium Ioannis XIII 9, 51) oskarżali gnostyków, że naginają tekst Pisma do swoich z góry przyjętych mitologizujących przesłanek. Por. M. Szram, Duchowy sens liczb $w$ alegorycznej egzegezie aleksandryjskiej (II-Vw.), Lublin 2001, 85.

${ }^{47}$ Chodzi o wspomnianych wyżej ofitów i kainitów. Por. Filastrius Brixiensis, Diuersarum hereseon liber 1-2, ed. Heylen - Banterle, s. 26. 
Jahwe wykorzystał jako narzędzie kary, np. żaby podczas plag egipskich, wyposażając je w związku z tym rzekomo w boską moc ${ }^{48}$. Do tej grupy herezji żydowskich, wywodzących swoje poglądy lub praktyki z błędnie rozumianych przekazów starotestamentalnych, zaliczył biskup Brescii także ugrupowanie składające ofiary miedzianemu wężowi (por. Lb 21, 9) w przekonaniu, że posiada on szczególną moc Bożą ${ }^{49}$.

Żydzi ze zrozumiałych względów nie dopuszczali myśli, że Mesjasz może być Bogiem. Filastriusz zwrócił jednak uwagę, że obok esseńczyków, którzy oczekiwali go jako proroka ${ }^{50}$, istniały w ich środowisku również ugrupowania negujące wszelki związek Mesjasza ze sferą Boską: według saduceuszy i ich prekursora Dozyteusza nie mógł on być ani aniołem ani duchem ${ }^{51}$; w przekonaniu faryzeuszy miał być tylko sprawiedliwym człowiekiem ${ }^{52}$. Wśród wczesnochrześcijańskich heretyków, wywodzących się ze środowiska judeochrześcijan, podobne poglądy głosili zwolennicy Karpokratesa, Cerynta i Ebiona, uważający, że Chrystus nie narodził się z dziewicy Maryi i Ducha Świętego, ale uznający go za zwykłego człowieka, który urodził się z nasienia Józe$\mathrm{fa}^{53}$; a także gnostycyzujący Teodot, pochodzący z Bizancjum, który nauczał o Chrystusie jako zwyczajnym człowieku, natomiast tego, co mówiono o Nim jako o Bogu, nie przyjmowat ${ }^{54}$.

Chociaż $\mathrm{w}$ judaizmie starotestamentalnym dopuszczano wiarę $\mathrm{w}$ powrót zmarłych do życia, czego przykładem są poglądy faryzeuszy ${ }^{55}$, zdarzały się ugrupowania, zdecydowanie odrzucające możliwość przyszłego zmartwychwstania, inspirujące późniejsze poglądy antyheretyckie we wczesnym chrześcijaństwie, na przykład w gnostycyzmie. Należeli do nich wspomniany Dozyteusz i kontynuatorzy jego myśli - saduceusze, a także samarytanie ${ }^{56}$. Ci ostatni - zgodnie z przekazem biskupa Brescii - negowali istnienie w człowieku nieśmiertelnej duszy, uważali, że życie ogranicza się tylko do doczesnej egzystencji w ciele, a pod pojęciem zmartwychwstania rozumieli powstawanie życia dokonujące się codziennie w świecie przez rodzenie dzieci ${ }^{57}$.

${ }^{48}$ Por. tamże 11, ed. Heylen - Banterle, s. 32-34.

${ }^{49}$ Por. tamże 21, 1-5, ed. Heylen - Banterle, s. 40.

${ }^{50}$ Por. tamże 9, 2, ed. Heylen - Banterle, s. 32: „Esseni [...] Christum autem deum dei filium non expectantes, nec in lege atque prophetis eum dominum agnoscentes adnuntiatum, sed ut prophetam aut iustum hominem solum credentes expectant".

${ }^{51}$ Por. tamże 4-5, ed. Heylen - Banterle, s. 28.

${ }^{52}$ Por. tamże 6, 1, ed. Heylen - Banterle, s. 28-29.

${ }^{53}$ Por. tamże 35-37, ed. Heylen - Banterle, s. 54-58.

${ }^{54}$ Por. tamże 50, 3, ed. Heylen - Banterle, s. 68: „Isti utuntur capitulis scripturarum quae de Christo veluti de homine edocent, quae autem ut de deo dicunt, ea vero non accipiunt".

${ }^{55}$ Por. tamże 6, 1, ed. Heylen - Banterle, s. 28.

${ }^{56}$ Por. tamże 4-5. 7, ed. Heylen - Banterle, s. 28. 30.

${ }^{57}$ Por. tamże 7, 2, ed. Heylen - Banterle, s. 30: ,animam etiam inmortalem habere hominum iuxta legem non sentientes, solum autem hoc in corpore uiuendum esse putantes, resurrectionemque futuram in procreatione filiorum, quae in hoc saeculo fit cotidie, hanc aestimantes". 
Filastriusz wspominał również o takich ugrupowaniach żydowskich, które gloryfikowały ludzkie ciało. Zaliczył do nich ponownie Dozyteusza i saduceuszy oraz nazirejczyków, głoszących, że wszelkie usprawiedliwienie polega na oddawaniu szacunku ciału, ze szczególnym uwzględnieniem pielęgnacji włosów, w nawiązaniu do umieszczonej we włosach siły biblijnego Samsona ${ }^{58}$. Poglądy te nie znalazły jednak kontynuacji wśród herezjarchów wczesnochrześcijańskich, skłonnych raczej do postawy przeciwnej: nawiązującej do platonizmu pogardy dla rzeczywistości materialnej i cielesnej, co znalazło odzwierciedlenie zwłaszcza w ruchach gnostyckich i manicheizmie ${ }^{59}$. Za inspirowany żydowskimi oczekiwaniami na Mesjasza politycznego oraz na wyzwolenie Izraela i rozumiany w kategoriach materialistycznych dobrobyt, rekompensujący doznane prześladowania i niewole, można natomiast uznać rozpowszechniający się od II w. w środowiskach judeochrześcijańskich chiliazm, głoszący w nawiązaniu do literalnej interpretacji tekstu Ap 21 tysiącletnie królowanie zmartwychwstałych sprawiedliwych wraz z Chrystusem w ziemskim dobrobycie. Ruch ten, jednoznacznie definiowany przez Filastriusza jako heretycki ${ }^{60}$, pierwotnie nie był uważany za zagrożenie dla ortodoksji, a jego zwolennikami byli m.in. Justyn, Ireneusz i Tertulian ${ }^{61}$. Dopiero próba wcielenia $\mathrm{w}$ życie poglądów millenarystycznych przez montanistów i lokalizacji tysiącletniego królestwa we Frygii sprawiła, że uznano chiliazm

${ }^{58}$ Por. tamże 8, 1-2, ed. Heylen - Banterle, s. 30: „heresis Iudaeorum qui dicuntur Nazorei, [...] carnaliter tamen uiuendum adfirmat, omnemque iustificationem in carnali obseruantia consistere suspicatur, crines etiam nutrientes capitis omnemque uirtutem iustitiae in eo putantes consistere". Przekaz Filastriusza o tym ugrupowaniu odbiega od opisu biblijnego (por. Sdz 13, 5-7; 6, 17) oraz relacji Epifaniusza (Panarion 18), zgodnie z którymi - wręcz przeciwnie - nazirejczycy dbali o ascezę cielesną i abstynencję od napojów alkoholowych, a niestrzyżenie włosów i bród było dla nich znakiem poświęcenia się Bogu.

${ }^{59}$ Por. Filastrius Brixiensis, Diuersarum hereseon liber 38, 6, ed. Heylen - Banterle, s. 58: „[Valentinus] anima ergo solam saluari, corpus autem hominis non saluari arbitratur"; tamże 61, 3, ed. Heylen - Banterle, s. 76: ,[Manichei] corpus autem a diabolo factum arbitrantur, resurrectionem negantes”.

${ }^{60}$ Por. tamże 59, 1: „Alia est heresis Chiliontaëtitarum, id est mille annorum, quae docet ita: Cum uenerit Christus de caelo, inquit, mille anni illi erunt nobis iterum carnaliter ad uiuendum, generandum et manducandum, sicut fit nunc in hoc saeculo cottidie".

${ }^{61}$ Por. Iustinus, Dialogus cum Iudaeo Tryphone 80, 5, ed. J.C.Th. Otto, w: Corpus Apologetarum Christianorum saeculi secundi, I/2, Wiesbaden 1969, 292, thum. L. Misiarczyk: Justyn Męczennik, Dialog z Żydem Tryfonem, w: tenże, 1 i 2 Apologia. Dialog z Żydem Tryfonem, War-

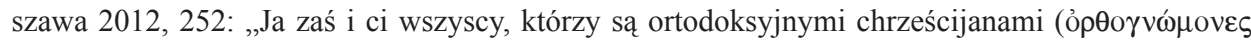

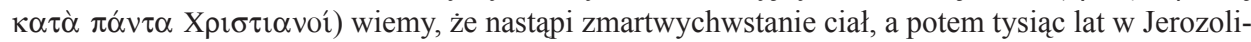
mie odbudowanej, upiększonej i powiększonej, jak to potwierdzają prorocy Ezechiel, Izajasz i inni prorocy"; Irenaeus, Adversus haereses V 33-35; Tertullianus, Adversus Marcionem III 24, 5. Zob. Il millenarismo. Testi dei secoli I-II, ed. C. Nardi, Biblioteca Patristica 27, Fiesole 1995, 123-124 i 144; M. Simonetti, Il millenarismo cristiano dal I al V secolo, ASE 15 (1998) fasc. 1, 7-20; G. Pani, Il millenarismo: Papia, Giustino e Ireneo, ASE 15 (1998) fasc. 1, 53-84; W. Myszor, Millenaryzm w ujęciu Ireneusza z Lyonu (Adversus haereses V, 30, 4 - 36, 3), TST 19 (2000) z. 1, 27-38; A. Delrio, Il millenarismo di Tertulliano, „Augustinianum” 43 (2003) 365-396. 
za błędne rozumienie wydarzeń eschatologicznych, a Orygenes ukierunkował interpretację tysiącletniego królestwa na duchowe tory ${ }^{62}$ i dostrzegł w nim obraz czasu Kościoła rozpoczynającego się dla każdego chrześcijanina od zmartwychwstania z grzechu podczas chrztu świętego ${ }^{63}$.

b) Geneza filozoficzna. Mimo że Filastriusz upatrywał genezy herezji chrześcijańskich przede wszystkim w judaizmie, czego dowodzi wspomniany układ kompozycyjny dzieła Diuersarum hereseon liber, nawiązujący do $\mathrm{Pa}$ narionu Epifaniusza, to jednak wielokrotnie przy omawianiu herezji wczesnochrześcijańskich odwoływał się do greckich idei filozoficznych, które mogły stać się inspiracją dla błędnych doktryn na gruncie chrześcijaństwa.

Obserwując sposób wypowiedzi biskupa Brescii odnosi się wrażenie, że nie miał on zaufania do starożytnych szkół filozoficznych. Reprezentował stanowisko zbliżone do tej grupy apologetów wczesnochrześcijańskich, której patronował Tertulian ze swoimi obawami przed zagrożeniami wobec nowej religii, płynącymi ze strony antycznej myśli filozoficznej ${ }^{64}$. Przekonanie to odbiegało od otwartej postawy aleksandryjczyków z Klemensem i Orygenesem na czele, którzy dostrzegali w filozofii greckiej wiele pozytywnych elementów rzekomo „skradzionych” od Żydów, z Pięcioksięgu Mojżeszowego ${ }^{65}$. Krytyczne podejście Filastriusza do filozofii, akcentujące raczej rozbieżności niż punkty wspólne z nauką Ewangelii, powraca w różnych miejscach jego traktatu:

„Tego, co twierdzą nieużyteczne opinie filozofów, Pismo nie naucza" ${ }^{\prime 66}$;

„najbardziej kłamliwi spośród poetów i stoickich filozofów nie zdają so-

bie sprawy, że rozumny człowiek ma ducha rozumnego od Boga, to znaczy

${ }^{62}$ Por. Origenes, De principiis II 11, 2-3; tenże, Commentarii in Matthaeum 17, 35. Zob. M. Simonetti, Il millenarismo in Oriente da Origene a Metodio, w: Corona gratiarum. Miscellanea E. Dekkers, Brugge 1975, 39-46; M. Szram, Orygenes a millenaryzm-jednoznaczne odrzucenie czy przyjęcie pewnych inspiracji, TST 19 (2000) z. 1, 39-53; H. Pietras, I Principi II, 11 di Origene e il millenarismo, w: Origeniana Octava. Origen and the Alexandrian Tradition. Papers of the $8^{\text {th }}$ International Origene Congress, Pisa, 27-31 August 2001, ed. L. Perrone, Leuven 2003, 707-714.

${ }^{63}$ Por. Origenes, Commentarii in Iohannem X 35, 231-232; tenże, Commentarii in Epistulam ad Romanos V 9. Zob. H. Crouzel, La „première” et la seconde” résurrection des hommes d'après Origène, „Didaskalia” 3 (1973) 12-17; M. Szram, Ciało zmartwychwstałe w myśli patrystycznej przełomu II i III wieku, Lublin 2010, 453-461.

${ }^{64}$ Por. Tertullianus, Apologeticum 46, 18. Zob. C. Moreschini, Storia della filosofia patristica, Brescia 2004, 181-187; M. Szram, Apologeci wczesnochrześcijańscy, w: Leksykon teologii fundamentalnej, red. M. Rusecki - K. Kaucha - I.S. Ledwoń - J. Mastej, Lublin - Kraków 2002, 71-78; tenże, Tertulian, PEF IX 448-451.

${ }^{65}$ Por. Clemens Alexandrinus, Stromata V 14, 89-141; tamże V 3, 28-34; Origenes, Contra Celsum IV 21. Zob. J.A. Wojtczak, Stosunek Klemensa Aleksandryjskiego do filozofii wedtug „, Stromata”, STV 9 (1971) z. 1, 263-288; H. Crouzel, Origène et la philosophie, Paris 1962, 167-172; Moreschini, Storia della filosofia patristica, s. 128-134.

${ }^{66}$ Filastrius Brixiensis, Diuersarum hereseon liber 99, 3, ed. Heylen - Banterle, s. 116: „Illud itaque filosoforum inanes sententiae adserunt, non scriptura diuina ita praedicat". 
może Boga poznać i w Niego wierzyć, natomiast zmysł ciała ma wspólny $\mathrm{z}$ bydłem" 67 .

Wymowę powyższych stwierdzeń wzmacnia przytoczenie przez Filastriusza Pawłowej przestrogi: „Uważajcie, aby was nie zwiódł ktoś przez filozofię i próżne zwodzenie zgodne z elementami świata, a nie z Chrystusem, ponieważ w Nim mieszka wszelka pełnia bóstwa na sposób ciała $(\mathrm{Kol} 2,8){ }^{\text {" } 68}$.

Filozofów i ich naukę biskup Brescii określał zwykle epitetami pochodzącymi ze słownika inwektyw: uanus - ,próżny”; ,zwodniczy”, ,głupi”" ${ }^{69}$; inanis - ,pusty”, ,pozorny" "70; falsus - „fałszywy" ";1; periculosus - ,niebezpieczny"72. mendacium - „kłamstwo" "73; impietas - „,bezbożność”74, dementia - „nierozumność”, „głupota"75. Większość z tych terminów pokrywa się z określeniami odnoszonymi przez biskupa Brescii do herezji wczesnochrześcijańskich ${ }^{76}$.

Wiele zagrożeń dla chrześcijańskiej doktryny dostrzegł Filastriusz w filozofii platońskiej, skądinąd niezwykle cenionej w epoce patrystycznej ${ }^{77}$. W poglądach Platona dopatrzył się inspiracji dla chrześcijańskich herezji deprecjonujących ciało, odrzucających możliwość jego zmartwychwstania i zbawienia, chociaż nie wskazywał wprost na inspiracje platońskie wobec głównego ruchu heretyckiego II w. o nastawieniu antymaterialistycznym i antyrezurekcyjnym, jakim był gnostycyzm. Omawiając naukę heretyków z Galacji - Seleucjusza

${ }^{67}$ Tamże 100, 1, ed. Heylen - Banterle, s. 116: „quidam de poetis et filosofis Stoicis uanissimi suspicantur, ignorantes quod homo rationabilis intellectum habet animi de deo, id est scire posse de deo et credere, sensum autem habet corporis cum pecudibus". Por. tamże 102, 2, ed. Heylen Banterle, s. 120: „Non adtendentes dei potentiam, elementorum naturae audent adscribere potentiae motionem, ut quidam filosofi uaniloqui, qui rerum naturae hoc adscribentes dei potentiam non cognouerunt”; tamże 114, 1, ed. Heylen - Banterle, s. 144: „Alia est heresis quae dicit mundos esse infinitos et innumerabiles, secundum filosoforum quorundam inanem sententiam".

${ }^{68}$ Por. tamże 123, 2, ed. Heylen - Banterle, s. 158.

${ }^{69}$ Por. tamże 124, 2, ed. Heylen - Banterle, s. 160: ,uanitatis filosoforum magis quam Christianitatis uidetur habere consortium”; tamże 125, 3, ed. Heylen - Banterle, s. 162: ,illi poetae uani et filosofi deorum dearumque appellationes hominum sensibus seminauerint".

${ }^{70}$ Por. tamże 114, 1, ed. Heylen - Banterle, s. 144: ,secundum filosoforum quorundam inanem sententiam”; tamże 133, 2, ed. Heylen - Banterle, s. 178: „magisque [...] filosoforum inanis sententiae, quam Christianae scientiae habere consortium".

${ }^{71}$ Por. tamże 103, 3, ed. Heylen - Banterle, s. 120: „falsique filosofi ausi sunt usurpantes suis mendaciis et alia plurima copulare atque impietatis semina saeculo praedicare".

${ }^{72}$ Por. tamże 142, 9, ed. Heylen - Banterle, s. 196: „filosofi [...] in periculosis sententiis confirmarunt".

${ }^{73}$ Por. tamże: „suae paganitatis mendacia transtulerunt”.

${ }^{74}$ Por. tamże: ,impietatisque semina in sono verborum [...] confirmarunt".

${ }^{75}$ Por. tamże 5, 2, ed. Heylen - Banterle, s. 28: „Epicuream dementiam potius quam divinae legis iura sectantes".

${ }^{76}$ Por. noty nr 9-16.

${ }^{77}$ Por. E. von Ivánka, Plato christianus. La réception critique du platonisme chez les Pères de l'Église, trad. de l'allemand E. Kessler, Paris 1990, passim; C. de Vogel, Platonismo e cristianesimo. Antagonismo o comuni fondamenti?, trad. E. Peroli, a cura di G. Reale-E. Peroli, Milano 1993, 51-91. 
i Hermiasza, biskup Brescii zwrócił uwagę na obecność w niej takich elementów zbieżnych z platonizmem, jak: z jednej strony - przekonanie, że materia świata jest współwieczna $z$ Bogiem, $\mathrm{z}$ drugiej - odrzucenie widzialnego raju ${ }^{78}$. Chodziło tu o zaprzeczenie możliwości przebywania człowieka po zmartwychwstaniu w odnowionym niebiańskim raju wraz z ciałem. Pogląd wspomnianych heretyków, że mogą tam przebywać tylko dusze ludzkie złożone z ognia i ducha $^{79}$, był wprawdzie nawiązaniem do biblijnych słów Jana Chrzciciela - „On chrzcić was będzie duchem i ogniem" (por. Mt 3, 11; Łk 3, 16), ale także wykazywał pokrewieństwo z przekonaniem o eteryczności duszy, a eter-zgodnie z poglądami przypisywanymi Platonowi - stanowił najbardziej świetlistą odmianę powietrza ${ }^{80}$. Opisana przez Filastriusza bez wymieniania nazwy herezja, uznająca - na podstawie tekstu „Uczyńmy człowieka na obraz i podobieństwo Boże" $(\operatorname{Rdz} 1,27)$ - że dusza ludzka jest z natury, a nie przez podobieństwo, spokrewniona z Bogiem, również wykazuje pewną zbieżność z platońskim pojmowaniem duszy rozumnej i nieśmiertelnej jako elementu boskiego ${ }^{81}$.

Filozoficzną - daleko wykraczającą poza platonizm - genezę błędnych poglądów na temat duszy uwypuklił Filastriusz relacjonując poglądy herezji głoszącej, że dusza ludzka zbudowana jest z któregoś z podstawowych elementów strukturalnych świata, czyli żywiołów ${ }^{82}$. Jej zwolennicy uważali, że dusza składa się albo z ognia - nawiązując w ten sposób do poglądów Heraklita ${ }^{83}$; albo z wody - zgodnie z przekonaniem Talesa z Miletu ${ }^{84}$; albo z materii

${ }^{78}$ Por. Filastrius Brixiensis, Diuersarum hereseon liber 55, 1. 4, ed. Heylen - Banterle, s. 70. 72: ,hylen etiam, id est materiam mundi coaeternam esse cum deo adserunt, [...] Paradisum uisibilem negant a Platone”. Zob. Plato, Timaeus 31b - 33a; tamże 69a. Na związki z Platońskim Timaiosem wskazał Filastriusz wprost w omówieniu herezji dotyczącej podziału świata na kraje i narody. Por. Filastrius Brixiensis, Diuersarum hereseon liber 121, 8-10, ed. Heylen - Banterle, s. 156.

${ }^{79}$ Por. Filastrius Brixiensis, Diuersarum hereseon liber 55, 4, ed. Heylen - Banterle, s. 72: „animas hominum de igne et spiritu esse aestimantes”.

${ }^{80}$ Por. Plato, Timaeus 58d. W Orygenesowskiej doktrynie o ciele zmartwychwstałym ważną rolę odgrywa nawiązujący do Platońskiej koncepcji eteru pogląd o eteryczności zmartwychwstałego ciała. Metody z Olimpu (De resurrectione II 30, 8) i Hieronim (Liber ad Pammachium contra Iohannem Hierosolymitanum Episcopum et Rufinum Origenis Adsertorem 26, 71-73) podejrzewali, że Orygenes pojmował eter jako mieszankę ognia i powietrza lub jako szczególny rodzaj powietrza. Por. Szram, Ciało zmartwychwstate, s. 600-603.

${ }^{81}$ Por. Filastrius Brixiensis, Diuersarum hereseon liber 137, 1-9, ed. Heylen - Banterle, s. 184. 186; Plato, Phaedo 79a - 80b; tenże, Timaeus 41b-d. Zob. G. Reale, Historia filozofii starożytnej, tłum. E.I. Zieliński, t. 2: Platon i Arystoteles, Lublin 1996, 221-228.

${ }^{82}$ Por. Filastrius Brixiensis, Diuersarum hereseon liber 126, 1, ed. Heylen - Banterle, s. 162: „Alia est heresis quae de censu animae ambigit et ex elementis eam consistere opinatur, ut multi filosofi uanissimi, nunc de igni, ninc de aqua, nunc de spiritu, nunc de materia, [...] nunc de atomis, nunc quasi aera esse animam hominis suspicantur".

${ }^{83}$ Por. Aristoteles, De anima 405a; Diogenes Laertius, Vitae philosophorum IX 1, 8. Zob. G. Reale, Historia filozofii starożytnej, t. 1: Od poczatków do Sokratesa, Lublin 1993, 98-101.

${ }^{84}$ Por. Aristoteles, Metaphysica A 3, 983b; Diogenes Laertius, Vitae philosophorum I 1, 27. Zob. Reale, Historia filozofii starożytnej, t. 1, s. 77-78. 
- jak sądzili stoicy ${ }^{85}$; albo z atomów - jak twierdził Demokryt ${ }^{86}$; albo wreszcie z powietrza - jak nauczał Anaksymenes ${ }^{87}$. Wprawdzie Filastriusz nie wymienił z imienia wspomnianych wyżej konkretnych filozofów, ale autorów przedstawionych poglądów - głównie reprezentantów archaicznej szkoły jońskiej - nietrudno zidentyfikować ${ }^{88}$.

Do nauczania Demokryta wymienionego tym razem przez Filastriusza z nazwiska, ale także do kosmologicznych poglądów stoickich, nawiązywała nieokreślona z nazwy herezja, głosząca że istnieje wiele nieskończonych i niezliczonych światów ${ }^{89}$. Do pitagorejskiej i platońskiej nauki o metempsychozie odwoływała się także omówiona przez biskupa Brescii herezja dotycząca pośmiertnych losów wielkich grzeszników: trucicieli, zbrodniarzy i zabójców (uenenarii, scelerati, homicidae) $^{90}$. Zwolennicy tej doktryny uważali, w nawiązaniu do pogańskiej wiary w wędrówkę dusz, że dusze przestępców

„wchodzą w demony, w bydło, w dzikie zwierzęta i w węże, nie rozumiejąc że dusza człowieka odchodząc z tego świata - czy to dobra czy zła, pobożna czy niepobożna - jest prowadzona przez anioła na ustanowione miejsce, aby na przyszłość otrzymać to, co zostało jej przeznaczone, w zależności od tego, co czyniła na tym świecie"

Wpływów pitagorejskich Filastriusz dopatrywał się również w ruchach gnostyckich, odwołujących się do symboliki liczb w tworzeniu mitologicznej

${ }^{85}$ Por. Fragmentum 90, w: Stoicorum Veterum Fragmenta, ed. H. von Arnim, t. 1: Zeno et Zenonis discipuli, Stuttgart 1964, 25; Fragmentum 329, w: Stoicorum Veterum Fragmenta, t. II: Chrysippi fragmenta logica et physica, Stuttgart 1964, 117. Zob. G. Reale, Historia filozofii starożytnej, t. 3: Systemy epoki hellenistycznej, Lublin 1999, 361-363.

${ }^{86}$ Por. Diogenes Laertius, Vitae philosophorum IX 7, 44. Zob. Reale, Historia filozofii starożyt$n e j$, t. 1 , s. 190-200.

${ }^{87}$ Por. Diogenes Laertius, Vitae philosophorum II 2, 3. Zob. Reale, Historia filozofii starożytnej, t. 1 , s. 89-92.

${ }^{88}$ Por. na temat filozofów jońskich: A. Krokiewicz, Zarys filozofii greckiej. Od Talesa do Platona, Warszawa 1971, 70-91; Reale, Historia filozofii starożytnej, t. 1, s. 73-102.

${ }^{89}$ Por. Filastrius Brixiensis, Diuersarum hereseon liber 114, 2, ed. Heylen - Banterle, s. 146: „ut et Democritus ille, qui multos mundos esse adseruit”; Diogenes Laertius, Vitae philosophorum IX 7, 44; Nemesius Emesianus, De natura hominis 38, 55. Zob. Reale, Historia filozofii starożytnej, t. 3, s. 389-390; J. Duda, Jeden świat czy wiele światów? Kosmologiczne podstawy doktryny Orygenesa, Siedlce 2008, 230.

${ }^{90}$ Por. Filastrius Brixiensis, Diuersarum hereseon liber 124, 1, ed. Heylen - Banterle, s. 158. Zob. Plato, Phaedo 81c - 82c; Diogenes Laertius, Vitae philosophorum VIII 1, 31-32. Zob. Reale, Historia filozofii starożytnej, t. 1, s. 118.

${ }^{91}$ Filastrius Brixiensis, Diuersarum hereseon liber 124, 1, ed. Heylen - Banterle, s. 158-160: „animas uenenariorum, sceleratorum et homicidarum et aliorum talium transire in daemonas ac pecudes et bestias et serpentes, ignorantes quod anima hominis cum exierit de saeculo, siue bona siue mala, id est pia atque impia, ab angelo ducitur in locum statutum, ut in futurum percipiat iuxta quod gessit in hoc saeculo constituta". 
doktryny o boskiej pleromie złożonej z określonej liczby eonów. O Walentynie biskup Brescii pisał z retoryczną przesadą zabarwioną inwektywą:

„bardziej pitagorejczyk niż chrześcijanin. Zionąc jakąś próżną i zgubną doktryną, oraz głosząc pełną fałszu arytmetyczną - czyli związaną z wielością - naukę, zwiódł wiele nieświadomych dusz"92.

Jednym z jego następców był Marek Mag, znany z arytmologicznych rozważań opartych na założeniu, że liczba, miara i rachunek (numerus, mensura, calculus $)^{93}$ mają wyjątkowe znaczenie w opisie rzeczywistości:

„Mówił tak: Są - powiada - 24 litery, które wyrażają doskonałość wszystkich rzeczy (uiginti quattuor [...] litterae sunt, quae perfectionem habent omnium rerum). Dlatego i Chrystus - jak mówi - stwierdził: «Ja jestem Alfa i Omega» (Ap 1, 8; 21, 6; 22, 13). Powiedział również, że w ostatnim czasie Chrystus zstapił na Jezusa pod postacią i na podobieństwo gołębicy, i nauczał, że ten sam Chrystus jest gołębica, która - jak mówi - zstąpiła na 12 Eonów, to znaczy na 12 Apostołów, oraz utrzymywał, że jeden z nich, to jest Judasz, upadł"94.

Stoicyzm - druga wielka szkoła filozoficzna starożytnej Grecji, która wywarła ogromny wpływ na etykę chrześcijańską ${ }^{95}$ - również mogła być, w przekonaniu Filastriusza, środowiskiem herezjogennym wobec formującej się doktryny chrześcijańskiej. Oskarżył on filozofów stoickich o głoszenie poglądów, które mogły zainspirować wczesnochrześcijańską herezję uznająca, że zwierzęta posiadają rozum podobny do ludzkiego ${ }^{96}$. Zwrócił też uwagę, że swoisty „materializm” stoicki mógł wpłynąć na błędne opinie niektórych chrześcijan na temat materialności duszy ${ }^{97}$.

92 Tamże 38, 1, ed. Heylen - Banterle, s. 58: „Pythagoricus magis quam Christianus, uanam quandam ac perniciosam doctrinam eructans et uelut arithmeticam, id est numerositatis notitiam fallacissimam praedicans, multorumque animas ignorantium captiuauit”. Por. tamże 38, 3-4, ed. Heylen - Banterle, s. 58: „Nihil erat aliud ante, inquit, in mundo, nisi Profundum maris et Silentium, [...] deque hoc Profundo et Silentio processisse Intellectum et Veritatem, de Intellectu autem et Veritate Verbum et Vitam, de Verbo autem et Vita Hominem et Ecclesiam: de Homine autem et Ecclesia processisse duodecim Aeonas, id est Saecula et de Verbo et Vita decem Aeonas processisse, de Intellectu autem et Veritate octo Aeonas, et esse hanc triacontada Saeculorum, id est triginta Aeonas Aeonon. De ogdoada ergo et decada et duodecada consistere triginta Aeonas deliberat".

${ }^{93}$ Por. tamże 42, 1, ed. Heylen - Banterle, s. 60.

${ }^{94}$ Tamże 42, 2-3, ed. Heylen - Banterle, s. 60.

${ }^{95}$ Por. M. Spanneut, Le stö̈cisme des Pères de l'Église de Clément de Rome à Clement de l'Alexandrie, Paris 1957, passim.

${ }^{96}$ Por. Filastrius Brixiensis, Diuersarum hereseon liber 100, 1, ed. Heylen - Banterle, s. 116: „Alia est heresis quae pecudes, serpentes et aues rationabiles arbitratur esse ut homines, sicut Manichei et Gnostici perditi et quidam de poetis et filosofis Stoicis uanissimi suspicantur".

${ }^{97}$ Por. tamże 126, 1, ed. Heylen - Banterle, s. 162: „Alia est heresis quae de censu animae ambigit et ex elementis eam consistere opinatur, ut multi filosofi uanissimi, $[\ldots]$ nunc de materia, $[\ldots]$ animam hominis suspicantur”. Należy pamiętać, że Tertulianowa koncepcja cielesności duszy nie jest tożsama z uznaniem jej za materialną. Pojęcie corpus miało dla Kartagińczyka znaczenie bytu 
Spośród mniej znanych kierunków filozoficznych starożytnej Grecji Filastriusz przywołał cyników. Ich misteria stały się - jego zdaniem - wzorem dla tajemniczych obrzędów sprawowanych w mieście Pepuza we Frygii przez Montana i jego zwolenniczki - Maksymillę i Pryscyllę ${ }^{98}$. Częścią tych obrzędów miało być mieszanie z ofiara paschalną krwi dziecka ${ }^{99}$, o czym wzmiankował także Epifaniusz, nic nie wspominając jednak o powiązaniach z cynizmem ${ }^{100}$.

Zgodnie $\mathrm{z}$ panującym jednomyślnie w epoce patrystycznej - chociaż prawdopodobnie nie w pełni słusznym - przekonaniem, które podzielał również Filastriusz, jedynym całkowicie błędnym i niemożliwym do pogodzenia z chrześcijaństwem kierunkiem antycznej filozofii greckiej był epikureizm ze swoimi tezami negacji opatrzności Bożej i hedonizmu jako głównego celu życiowego ${ }^{101}$. Zrozumiałe jest więc, że w tym nurcie filozoficznym upatrywał biskup Brescii szczególne niebezpieczeństwo dla prawowierności doktryny chrześcijańskiej. Do epikurejczyków porównał Filastriusz najpierw żydowskich saduceuszy ze względu na propagowanie przez nich cielesnego sposobu życia ${ }^{102}$. Zapewne w poglądach nie tylko Demokryta, ale i Epikura - chociaż nie wymieniał imion tych filozofów - doszukiwał się także inspiracji dla poglądów niektórych chrześcijan przekonanych, że dusza ludzka składa się $\mathrm{z}$ atomó $\mathrm{w}^{103}$. Za zbieżne $\mathrm{z}$ epikurejskimi uważał błędne przekonania heretyków dotyczące używania przyjemności doczesnego życia na wzór bezmyślnych zwierząt ${ }^{104}$.

istniejącego. Wszystko, co istnieje, nawet Bóg, ma - według Tertuliana - swoje corpus dostosowane do natury konkretnego bytu: w przypadku Boga jest nim duch, w odniesieniu do duszy również chodziło o komponent duchowy i - ewentualnie - o jakiś bardzo subtelny gatunek towarzyszącej jej materii, dostosowanej do duchowego charakteru duszy. Zob. Tertullianus, Adversus Praxean 7, 8; tenże, De carne Christi 11, 3-4; tenże, De anima 8, 2 - 9, 6. Por. A. Filipowicz, Koncepcja duszy w pismach Tertuliana, Episteme 63, Olecko - Warszawa 2007, 104-105; Szram, Ciało zmartwychwstate, s. 178 i 247-250.

${ }^{98}$ Por. Filastrius Brixiensis, Diuersarum hereseon liber 49, 5, ed. Heylen - Banterle, s. 66: „Vbi et mysterium cynicon [...] celebratur". Zob. na temat odrodzenia się cynizmu w epoce Cesarstwa: G. Reale, Historia filozofii starożytnej, t. 4: Szkoty epoki cesarstwa, Lublin 1999, 233-261.

${ }_{99}$ Por. Filastrius Brixiensis, Diuersarum hereseon liber 49, 5, ed. Heylen - Banterle, s. 66-68: „infantis execranda celebratur impietas. Dicunt enim eos de infantis sanguine in pascha miscere in suum sacrificium".

${ }^{100}$ Por. Epiphanius, Panarion 48, 14.

${ }^{101}$ Por. Origenes, Contra Celsum III 75; tamże IV 14. Zob. Crouzel, Origène et la philosophie, s. 27-31; M. Szram, Chrystus - Mądrość Boża a madrość władców tego świata wedtug Orygenesa, w: Ojcowie Kościoła wobec filozofii i kultury klasycznej, red. F. Drączkowski - J. Pałucki M. Szram, Lublin 1998, 113-114.

${ }^{102}$ Por. Filastrius Brixiensis, Diuersarum hereseon liber 5, 2, ed. Heylen - Banterle, s. 28: „Epicuream dementiam potius quam diuinae legis iura sectantes".

${ }^{103}$ Por. tamże 126, 1, ed. Heylen - Banterle, s. 162: „filosofi uanissimi [...] nunc de atomis [...] animam hominis suspicantur".

${ }^{104}$ Por. tamże 134, 3, ed. Heylen - Banterle, s. 180: „Ergo quod ait apostolus de quibusdam: «Manducemus et bibamus, cras enim moriemur»; quod profecto paganorum, et Epicureorum est 
4. Wnioski końcowe. Pierwszy zachowany w języku łacińskim katalog herezji pióra Filastriusza z Brescii zawiera szereg uwag dotyczących genezy ruchów heterodoksyjnych we wczesnym chrześcijaństwie. Poglądy te zostały wplecione w omówienie poszczególnych herezji i nie tworzą systematycznego wykładu na temat ich pochodzenia. Powyższe wydobycie tych przekonań i sumaryczne ich przedstawienie pozwala jednak wysnuć kilka podsumowujących wniosków, wskazujących na charakterystyczne cechy podejścia Filastriusza.

Zgodnie z argumentacją biblijno-teologiczną biskupa Brescii wszelkie błędy pojawiające się w Kościele chrześcijańskim, podobnie jak odstępstwa od prawdy dostępnej wszystkim ludziom przed pojawieniem się chrześcijaństwa, pochodzą od szatana jako ojca kłamstwa. Kontynuacją tego wnioskowania jest argumentacja moralna, obarczająca odpowiedzialnością za powstanie herezji ludzi ulegających pod wpływem pokusy szatana wadzie pychy i nieposłuszeństwa, prowadzącej do tworzenia własnych nauk i wspólnot odrębnych od głównego nurtu „Wielkiego Kościoła”.

Dwuczłonowy układ dzieła Diuersarum hereseon liber, podobny do struktury Panarionu Epifaniusza z Salaminy, na którym najprawdopodobniej Filastriusz się wzorował, sugeruje, że biskup Brescii za główne herezje przedchrześcijańskie, stanowiące wzór dla późniejszych, uważał przedstawione w pierwszej części swojego traktatu błędy w łonie judaizmu, monoteistycznej religii objawionej, której swoistą kontynuacją jest chrześcijaństwo. Autor traktatu zwrócił uwagę zarówno na ruchy, które przez Żydów starotestamentalnych zostały uznane za heretyckie (np. ofici, kajanie, heliogności, czciciele Baala), jak i takie, które sam jako chrześcijanin uznał za niezgodne z prawdą (np. saduceusze, faryzeusze, nazarejczycy, esseńczycy).

Wiele błędów doktrynalnych we wczesnym chrześcijaństwie, zwłaszcza z zakresu kosmologii, antropologii czy etyki, przyporządkował Filastriusz błędnym poglądom trzech głównych kierunków filozoficznych starożytnej Grecji: platonizmu, stoicyzmu i epikureizmu. Zgodnie z podejściem rozpowszechnionym w epoce patrystycznej w dwóch pierwszych nurtach dostrzegał pewne niebezpieczeństwa, nie odrzucając jednak w całości głoszonych przez nie koncepcji, natomiast $\mathrm{w}$ trzecim widział same zagrożenia dla chrześcijańskiej nauki o Bożej Opatrzności oraz dla etyki.

Pod względem sposobu ukazania genezy herezji wczesnochrześcijańskich katalog herezji Filastriusza wykazuje podobieństwo do wcześniejszego o kilka lat obszernego dzieła Panarion Epifaniusza. U biskupa Salaminy wątek żydowski był jeszcze bardziej rozbudowany. Epifaniusz poświęcił oddzielny punkt błędnym ruchom religijnym wywodzącym się ze środowiska samarytańskiego,

talis heresis, quae uitae pecudum comparatur". Przekonanie o hedonizmie jako dominującym poglądzie szkoły epikurejskiej jest ostatnio podawane przez badaczy w wątpliwość. Por. I. Ronca, Cura dell'anima ed esercizio dello spirito nella filosofia epicurea, w: Cultura e promozione umana. La cura del corpo e dello spirito nell'antichità classica e nei primi secoli cristiani. Un magistero ancora attuale?, a cura di E. Dal Covolo - L. Giannetto, Troina 1998, 101-113. 
które uważał za szczególnie herezjogenne, podczas gdy u Filastriusza samarytanie zostali przedstawieni jako jedna $\mathrm{z}$ wielu sekt żydowskich ${ }^{105}$.

Obserwując wpływ dziełka biskupa Brescii na innych autorów łacińskich, należy stwierdzić, że było ono inspiracją dla późniejszego o kilkadziesiąt lat katalogu herezji, napisanego przez Augustyna ${ }^{106}$. Biskup Hippony ograniczył jednak wątek judaistycznej genezy ruchów heretyckich i skupił się w swoim dziele wyłącznie na ugrupowaniach wczesnochrześcijańskich, upatrując ich genezy głównie we wpływach ze strony starożytnych szkół filozoficznych ${ }^{107}$.

W kwestii poglądów na genezę herezji bliżej było do stanowiska Filastriusza Izydorowi z Sewilli, który u schyłku epoki patrystycznej na Zachodzie opracował niewielki katalog herezji wzorowany na dziełku biskupa Brescii. Wyliczył w nim na końcu najpierw herezje żydowskie, skupiające się wokół idei odmawiania bóstwa Chrystusowi, a następnie poglądy najważniejszych starożytnych szkół filozoficznych, nazwane ,pogańskimi prawdami” (gentilium dogmata), które mogły zainspirować heretyków ${ }^{108}$. W ten sposób - podobnie jak Filastriusz - połączył dwa źródła wczesnochrześcijańskich ruchów heretyckich, nie rozstrzygając, które z nich bardziej zaważyło na ich powstaniu i doktrynie.

\section{THE ORIGIN OF EARLY CHRISTIAN HERESIES ACCORDING TO PHILASTRIUS OF BRESCIA}

\section{(Summary)}

The original Latin catalogue of heresies, produced by Saint Philastrius of Brescia in the second half of IV ${ }^{\text {th }}$ century, encompasses several observations regarding the source of early Christian heterodox movements. These views are dispersed and interwoven into the analysis of particular heresies, and as such do not constitute an integral and standalone teaching on the nature of unorthodoxy and its genesis. The present work attempts at enucleating this standpoint and summarising it in a comprehensive and complementary manner.

Regarding the issue of the foundation of heresy, Philastrius proposed his own point of view based on the following threefold argumentation: the theological (Satan is the father of all the world's heterodoxy - comprehended as a lapse form God's truth), the moral (heresies rise due to one's pride), and historical and cultural (errors in early Christian doctrine derive from the Judaic sects or else from the counterfactual views of the ancient Greek philosophers).

${ }^{105}$ Por. nota nr 44.

${ }^{106}$ Por. Banterle, Introduzione, s. 10-12.

${ }^{107}$ Por. Augustinus, De haeresibus, Praefatio 5.

${ }^{108}$ Por. Isidorus Hispalensis, De haeresibus liber 59, ed. A.C. Vega, PLS 4, Paris 1967, 1819, thum. M. Cholewa: Świętego Izydora, biskupa Sewilli, Księga o herezjach, WST 6 (1993) 77. 
Philastrius' perspective refers back to an extensive and modestly younger work Panarion by Epiphanius of Salamis, in which the topic of Jewish-deriving deviations from the doctrine was treated even more at length. The Bishop of Brescia's index has been the inspiration for the later catalogues of unorthodoxy by St. Augustine (narrow in the topic of Judaic origins of heretical movements and rather focused on influences from the ancient philosophical schools) and Isidore of Seville (intermingling both sources of early heretical movements - i.e. Judaic and Greek - withholding the determination which of them has in fact more influenced the uprising of heterodoxy and the doctrine itself).

Translated by Michał Matusiak

Key words: Philastrius of Brescia, early Christian heresies, Judaism, ancient Greek philosophy, Platonism, Stoicism, Epicureanism, Gnosticism, Manichaeism, Montanism.

Słowa kluczowe: Filastriusz z Brescii, herezje wczesnochrześcijańskie, judaizm, starożytna filozofia grecka, platonizm, stoicyzm, epikureizm, gnostycyzm, manicheizm, montanizm.

\section{BIBLIOGRAFIA}

\section{Źródła \\ 1. Podstawowe}

Filastrius Brixiensis, Diuersarum hereseon liber, ed. F. Heylen - G. Banterle, Scriptores circa Ambrosium 2, Milano - Roma 1991.

\section{Uzupełniające}

Augustinus, De haeresibus ad Quodvultdeum liber unus, ed. R. Vander Plaetse - C. Beukers, Turnholti 1969, CCL 46, 266-345.

Augustinus, De utilitate credendi, ed. J. Zycha, CSEL 25/1, Pragae - Vindobonae - Lipsiae 1891, 3-48, tłum. J. Sulowski: Św. Augustyn, O pożytku wiary, w: Św. Augustyn, Pisma przeciw manichejczykom, PSP 54, Warszawa 1990, 33-65.

Basilius Caesariensis, Adversus Eunomium, ed. B. Sesboüé - G.-M. de Durand - L. Doutreleau, SCh 299, Paris 1982.

Basilius Caesariensis, De humilitate hom., PG 31, 525-540.

Clemens Alexandrinus, Stromata, V, ed. A. le Boulluec, SCh 278-279, Paris 1981; VI, ed. P. Descourtieux, SCh 446, Paris 1999, tłum. J. Niemirska-Pliszczyńska: Klemens Aleksandryjski, Kobierce zapisków filozoficznych dotyczacych prawdziwej wiedzy, t. 1-2, Warszawa 1994.

Diogenes Laertius, Vitae philosophorum, ed. H.S. Long, t. 1-2, Oxonii 1964, tłum. I. Krońska: Diogenes Laertios, Żywoty i poglady stynnych filozofów, Warszawa $1988^{4}$. Epihanius, Panarion, ed. K. Holl, 1-33, GCS 25, Leipzig 1915, 162-464, thum. M. Gilski: Epifaniusz z Salaminy, Panarion. Herezje 1-33. Tekst grecki i polski, Kraków 2015; 34-64, GCS 31, Leipzig 1922; 65-80, GCS 37, Leipzig 1933. 
Gregorius Nazianzenus, Orationes, 4-5, ed. J. Bernardi, SCh 309, Paris 1983; 27-31, ed. P. Gallay, SCh 250, Paris 1978; 32-37, ed. P. Gallay - C. Moreschini, SCh 318, Paris 1985, tłum. zbiorowe, w: Grzegorz z Nazjanzu, Mowy wybrane, red. S. Kazikowski, Warszawa 1967.

Gregorius Nyssenus, De mortuis non esse dolendum, ed. G. Heil, GNO 9: Sermones, Leiden 1967, 28-68.

Gregorius Nyssenus, De virginitate, ed. M. Aubineau, SCh 119, Paris 1966.

Gregorius Nyssenus, De vita Moysis, ed. J. Daniélou, SCh 1bis, Paris 1987, tłum. S. Kalinkowski: Św. Grzegorz z Nyssy, Życie Mojżesza, ŹMT 50, Kraków 2009.

Irenaeus, Adversus haereses, I, ed. A. Rousseau - L. Doutreleau - B. Hemmerdinger Ch. Mercier, SCh 263-264, Paris 1979; V, SCh 152-153, Paris 1969.

Isidorus HisPalEnsis, De haeresibus liber, ed. A.C. Vega, PLS 4, Paris 1970, 1815-1820, tłum. M. Cholewa: Świętego Izydora, biskupa Sewilli, Księga o herezjach, WST 6 (1993) 59-81.

Iustinus, Apologiae pro Christianis (Apologia I-II), ed. J.C.Th. Otto, Corpus Apologetarum Christianorum saeculi secundi, I/1, Wiesbaden 1969, 1-243, tłum. L. Misiarczyk: Justyn Męczennik, 1 i 2 Apologia, w: tenże, 1 i 2 Apologia. Dialog z Żydem Tryfonem, Warszawa 2012, 43-100.

Iustinus, Dialogus cum Iudaeo Tryphone, ed. J.C.Th. Otto, w: Corpus Apologetarum Christianorum saeculi secundi, I/2, Wiesbaden 1969, thum. L. Misiarczyk: Justyn Męczennik, Dialog z Żydem Tryfonem, w: tenże, 1 i 2 Apologia. Dialog z Żydem Tryfonem, Warszawa 2012, 159-318.

JoAnnes Chrisostomus, In Johannem hom., PG 59, 23-482.

Joannes Chrisostomus, In Ozias hom. (In illud: Vidi Dominum), ed. J. Dumortier, SCh 277, Paris 1981.

Joannes Damascenus, De haeresibus, ed. B. Kotter, Die Schriften des Johannes von Damaskos, t. 5, Berlin 1980, tłum. A. Zhyrkova: Jan Damasceński, O herezjach, w: Jan Damasceński, Dialektyka albo rozdziały filozoficzne. O herezjach, ŹMT 59, Kraków 2011, 105-139.

Origenes, Contra Celsum, III-IV, ed. M. Borret, SCh 136, Paris 1968, tłum. S. Kalinkowski: Orygenes, Przeciw Celsusowi, Warszawa 1986.

Origenes, De principiis, I-II, ed. H. Crouzel - M. Simonetti, SCh 252-253, Paris 1978, tłum. S. Kalinkowski: Orygenes, O zasadach, ŹMT 1, Kraków 1996.

Origenes, Comentarii in Iohannem, ed. C. Blanc, VI i X, SCh 157, Paris 1970; XIII, SCh 222, Paris 1975, tłum. S. Kalinkowski: Orygenes, Komentarz do Ewangelii wedtug św. Jana, ŹMT 27, Kraków 2003.

Plato, Phaedo, ed. R.D. Archer-Hind, London 1894², thum. W. Witwicki: Platon, $\mathrm{Fe}$ don, w: Platon, Uczta, Eutyfron, Obrona Sokratesa, Kriton, Fedon, Warszawa 1984, 351-485.

Plato, Timaeus, ed. R.D. Archer-Hind, London 1888, tłum. P. Siwek: Platon, Timajos, w: Platon, Timajos, Kritias albo Atlantyk, Warszawa 1986, 19-128.

Tertullianus, Adversus Marcionem, ed. A. Kroymann, CCL 1, Turnholti 1954, 441-726, tłum. S. Ryznar: Tertulian, Przeciw Marcjonowi, PSP 58, Warszawa 1994.

Tertullianus, Contra Valentinianos, ed. J.-C. Fredouille, SCh 280-281, Paris 1980.

Theodoretus, Haereticarum fabularum compendium, PG 83, 335-556. 


\section{Opracowania}

Banterle G., Introduzione, w: Filastrii Brixiensis Diuersarum hereseon liber, introd., trad., note e indici di G. Banterle, Roma 1991, 9-18.

BARDy G., Le „De haeresibus” et ses sources, w: Miscellanea agostiniana, t. 2, Roma 1931, 397-416.

Crouzel H., Origène et la philosophie, Paris 1962.

Delrio A., Il millenarismo di Tertulliano, „Augustinianum” 43 (2003) 365-396.

Filipowicz A., Koncepcja duszy w pismach Tertuliana, Episteme 63, Olecko - Warszawa 2007.

Gilski M., Epifaniusz z Salaminy i jego „Panarion”, w: Epifaniusz z Salaminy, Panarion. Herezje 1-33. Tekst grecki i polski, przekład i wstęp M. Gilski, opr. i kom. A. Baron, Kraków 2015, 5-20.

Il millenarismo. Testi dei secoli I-II, ed. C. Nardi, Biblioteca Patristica 27, Fiesole 1995.

Ivánka E. von, Plato christianus. La réception critique du Platonisme chez les Pères de l'Église, Paris 1990.

Krokiewicz A., Zarys filozofii greckiej (Od Talesa do Platona), Warszawa 1971.

Le Boulluec A., La notion d'hérésie dans la littérature grecque: II et III siècles, t. 1-2, Paris 1985.

MCClure J., Handbooks against Heresy in the West, from the Late Fourth to the Late Sixth Centuries, JTS 30 (1979) 186-197.

Myszor W., Millenaryzm w ujęciu Ireneusza z Lyonu (Adversus haereses V, 30, 4 - 36, 3), TST 19 (2000) z. 1, 27-38.

Pani G., Il millenarismo: Papia, Giustino e Ireneo, ASE 15 (1998) fasc. 1, 53-84.

Reale G., Historia filozofii starożytnej, thum. E.I. Zieliński, t. 1: Od poczatków do Sokratesa, Lublin 1993; t. 2: Platon i Arystoteles, Lublin 1996; t. 3: Systemy epoki hellenistycznej, Lublin 1999; t. 4: Szkoły epoki cesarstwa, Lublin 1999; t. 5: Słownik, indeksy i bibliografia, Lublin 2002.

Simonetti M., Il millenarismo cristiano dal I al V secolo, ASE 15 (1998) fasc. 1, 7-20.

Spanneut M., Le stö̈cisme des Pères de l'Église de Clément de Rome à Clement de l'Alexandrie, Paris 1957.

Szram M., Ciało zmartwychwstałe w myśli patrystycznej przełomu II i III wieku, Lublin 2010.

SzRam M., Cnota pokory w nauczaniu greckich Ojców Kościoła IV wieku, Lublin 2014.

SzRAm M., Orygenes a millenaryzm - jednoznaczne odrzucenie czy przejęcie pewnych inspiracji?, TST 19 (2000) z. 1, 39-53.

Vogel de C., Platonismo e cristianesimo. Antagonismo o comuni fondamenti?, a cura di G. Reale - E. Peroli, Milano 1993.

WIDOK N., Ortodoksja, herezja, schizma - wyjaśnienie pojęć, w: Ortodoksja, herezja, schizma w Kościele starożytnym, red. F. Drączkowski - J. Pałucki - P. Szczur - M. Szram - M. Wysocki - M. Ziółkowska, Lublin 2012, 15-34.

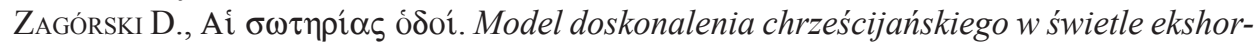
tacji pastoralnych Grzegorza z Nazjanzu, Torun 2007. 
